\title{
Effects of Cold Pressed Moringa Seed Oil on Nutrition and Health
}

\author{
Osman Kola (Corresponding author) \\ Adana Science and Technology University, Faculty of Engineering, \\ Department of Food Engineering, 01250, Adana-Turkey \\ E-mail: okola@atu.edu.tr \\ Erva Parildi \\ Adana Science and Technology University, Faculty of Engineering, \\ Department of Food Engineering, 01250, Adana-Turkey \\ Nurten Cengiz \\ Adana Science and Technology University, Faculty of Engineering, \\ Department of Food Engineering, 01250, Adana-Turkey \\ Murat Reis Akkaya \\ Adana Science and Technology University, Faculty of Engineering, \\ Department of Food Engineering, 01250, Adana-Turkey \\ Ali Emrah Cetin \\ Adana Science and Technology University, Faculty of Engineering, \\ Department of Food Engineering, 01250, Adana-Turkey
}

This research did not receive any specific grant from funding agencies in the public, commercial, or not-for-profit sectors.

\begin{abstract}
Some physicochemical characteristics and fatty acid composition of Moringa seed oil was analyzed. The seed oil was obtained by cold press. Moringa seed contains $4.92 \%$ moisture, $42.15 \%$ fat, $35.54 \%$ protein, $2.98 \%$ ash, $8.44 \%$ dietary fiber and $14.41 \%$ carbohydrate in the dry matter. Oleic acid was the main fatty acid (74.29\%) and it was followed by behenic acid (6.09\%), palmitic acid (5.83\%), stearic acid (4.67\%), arachidic acid $(3.32 \%)$ and gadoleic acid $(2.37 \%)$, respectively. Moringa oil had a total saturated fatty acid (SFA) content of about $21.39 \%$ and a total unsaturated fatty acid (TUFA) content of about $78.58 \%$. Total antioxidant and total phenolic substance amounts were $22.28 \mathrm{mM}$ Trolox/ml and $455.33 \mathrm{mg}$ gallic acid/g, respectively. The moringa seed has very high fat and protein contents and the fatty acid composition indicates that the seed oil of Moringa oleifera is included in high-oleic oils category, and has a high MUFA/SFA ratio.
\end{abstract}

Keywords: Moringa oleifera; oil; free fatty acid; oleic acid; behenic acid

DOI: $10.7176 / \mathrm{JSTR} / 6-01-03$

\section{Introduction}

Moringa oleifera Lam. (M. oleifera) also termed as "miracle tree" is the most cultivated species of Moringa which is the sole genus belonging to Moringaceae family (Bolarinwa et al., 2017; Coz-Bolaños et al., 2018; Da Porto et al., 2016). Moringa oleifera is a multi-purpose small-sized tree with its rich nutritional composition and medicinal importance (Vaknin and Mishal, 2017; Villaseñor-Basulto et al., 2018). Moringa oleifera is widely used for diabetes, sore throat, eye infections, skin sores, anemia, cholera and some other diseases (Chin et al., 2018; Choi et al., 2016). It has also antioxidant, antimicrobial, anticancer, anti-inflammatory, antitumor, antihypertensive, antifungal, hepatoprotective, analgesic, diuretic, coagulant, ulcer-protective and antidiabetic characteristics (Chin et al., 2018; González-Trujano et al., 2018; Omotoso et al., 2018; Zhao and Zhang, 2013). Moringa tree produces a natural polymer known as "moringa gum" and it comprises of $25.9 \%$ galactose, $5.6 \%$ rhamnose and trace 
amount of uronic acid (Abhishek et al., 2017).

Azeez et al. reported that Moringa oleifera is a complete food in itself due to containing more vitamin A than carrots, more vitamin $\mathrm{C}$ than oranges, more calcium than milk and more iron than spinach (Azeez et al., 2013). Rashid et al. investigated fatty acid compositions of some vegetable oils such as palm, canola, soybean and sunflowers and they found that the moringa oil is the oil with the highest oleic acid content at a ratio of $72.2 \%$ when compared to other oils (Rashid et al., 2008). According to Bhutada et al. the flower extracts of moringa have hepatoprotective effect (Bhutada et al., 2016).

Moringa oleifera leaves are suitable for a large number of applications such as preparing infusion and aqueous beverages, feedstock for biogas, animal feed, industrial and traditional medicinal uses (AbdElhakim et al., 2018; Coz-Bolaños et al., 2018; Vaknin and Mishal, 2017). Moringa oleifera leaves are very rich in some antioxidant compounds, tannins, steroids, triterpenoids, flavonoids, saponins, anthraquinones, alkaloids, niazimicin moringin, minerals, proteins and reducing sugar (Chin et al. 2018). In addition, chlorogenic acid, rutin, vicenin-2, quercetin, gallic acid and kaempferol are also bioactive compounds found in Moringa oleifera (Chin et al., 2018). Moringa oleifera leaves also have wound healing properties, strong antioxidant and free radical scavenging activities due to the presence of bioactive compounds such as ascorbic acid, phenolics and carotenoids (Chin et al. 2018).

Depending on the variety, Moringa seed kernels contain up to $30-60 \%$ of oil which is commercially known as "Behen oil" or "Ben oil" (Fakayode and Ajav, 2016; Valdés-Rodríguez et al., 2018). The lipid content of the plant changes depending on environmental conditions and harvesting practices (VillaseñorBasulto et al., 2018). Moringa oleifera oil is known to have very high amounts of oleic acid (70\%), palmitic acid, stearic acid, behenic acid, quercetin, luteolin and tocopherols (Martins et al., 2016; Mat Yusoff et al., 2016; Omotoso et al., 2018). The oil can be used as cooking oil, in treatment of arthritis, rheumatism, hypertension, also in cosmetic industry as an emulsifier (Bhutada et al., 2016; Fotouo-M. et al., 2016; Martins et al., 2016). The oxidative stability of Moringa oleifera oil is higher than canola oil, palm oil and soybean oil in terms of using as frying oil (Martins et al., 2016; Mat Yusoff et al., 2016; Omotoso et al., 2018). Fatty acid composition of the oil is equvalent to olive oil. This oil is also used in medical and mechanical industry (Martins et al., 2016).

In this study, some physicochemical properties and fatty acid composition of seed oil of moringa plant grown in Tamil Nadu, India have been determined. In addition to important nutrients such as protein and fat content, some properties of oil obtained by cold press from moringa seeds used in this study and nutrition and health effects of fatty acid components are discussed.

\section{Materials and methods}

\subsection{Materials}

Moringa seeds were obtained from SVM Exports, Tamil Nadu, India. All chemicals used in this research were supplied from Sigma-Aldrich Chemie GmbH (Germany) and all of them were of ACS-grade or better quality.

\subsection{Extraction}

Moringa seed oil extract was obtained by using a NF-500 model cold press (Karaerler Makina, Ankara, Turkey). The extraction was performed at $45^{\circ} \mathrm{C}$ and $10 \mathrm{MPa}$. The extracted oil sample was analyzed as soon as possible or stored at $20^{\circ} \mathrm{C}$ for a short time until analyzed.

\subsection{Physicochemical Characteristics}

The moisture content of the moringa seed powder was carried out according to AOAC method and to determine the total protein content Kjeldahl method (AOAC, 1990) was used after lipid extraction. To determine total dietary fiber, Megazyme Assay Kit (Procedure K-TDFR 2012, Megazyme International Ireland) based on AACC method 32-05.01 and AOAC method 985.29 was used (AOAC, 1990). Determination of the total oil content was performed using petroleum ether by Soxhlet extraction for 8 hours.

Color of the oil was evaluated by Lovibond method of AOCS, 2017, Cc 13e-92 using a glass cell with an optical path length of $133.35 \mathrm{~mm}$ (5 1/4") with PFX 880 Tintometer (Lovibond PFX 880 Tintometer Series, UK). Dry matter determination was carried out by drying in an oven at $105^{\circ} \mathrm{C}$ to constant weight. To determine the FFA content, peroxide value (POV) and iodine value (IV) American Oil Chemists' Society (AOCS) methods, Ca 5a-40, Cd 8-53 and Cd 1-25 were used, respectively. The degree of unsaturation was evaluated by using the equation with computed values obtained from GC after a comparison with the reference standards described by Porzucek and Raznikiewicz (Porzucek and Raznikiewicz, 1990).

27 | $\mathrm{P}$ a g e 


\subsection{Fatty Acid Profile Determination}

Fatty acid methyl esters (FAMEs) were prepared from the oil samples based on a laboratory protocol performed previously (Lutterodt et al., 2011; Yu et al., 2002). Briefly, $1 \mathrm{mg}$ of oil and $0.1 \mathrm{~mol} / \mathrm{L} \mathrm{NaOH}-$ $\mathrm{MeOH}$ were reacted with each other for $5 \mathrm{~min}$, and then reacted with $1.1 \mathrm{~mol} / \mathrm{L} \mathrm{HCl}-\mathrm{MeOH}$ for 5 minutes at ambient temperature. FAMEs were extracted with isooctane after adding water to stop the reaction. GC analysis was carried out with a Shimadzu GC-2010 equipped with a FID and a Shimadzu AOC-20i autosampler (Shimadzu, Columbia, MD). The analysis was carried out with a fused silica capillary column Teknokroma TR-CN100 (100 m $\times 0.25 \mathrm{~mm}$ with a $0.2 \mathrm{~mm}$ film thickness $)$ from Ant Teknik (İstanbul, Turkey) and helium was used as the carrier gas. The flow rate was $0.8 \mathrm{~mL} / \mathrm{min}$ and the injection volume was $1 \mu \mathrm{L}$ at a split ratio of $10 / 1$. Primary temperature was $142^{\circ} \mathrm{C}$ and raised to $184^{\circ} \mathrm{C}$ by increasing $6^{\circ} \mathrm{C} / \mathrm{min}$, held for $3 \mathrm{~min}$, and then raised to $244^{\circ} \mathrm{C}$ by increasing $6^{\circ} \mathrm{C} / \mathrm{min}$. Individual FAMEs were identifed by comparing the retention times with the help of FAME standards. To quantify the identified fatty acid, the area under each fatty acid peak relative to the total area of all fatty acid peaks was used. Results are given in $\mathrm{g}$ fatty acid/100 $\mathrm{g}$ total fatty acids. All samples used in this research were analyzed in duplicate.

\subsection{Total Phenolic Content}

The total phenolic content of moringa oil was carried out by the Folin-Ciocalteu method by Cemeroğlu (Cemeroğlu, 2018). Absorbance was measured by Agilent Carry $60 \mathrm{UV}$ - Vis at $765 \mathrm{~nm}$. The calibration curve was plotted by gallic acid standard solutions (Merck) between 5-500 mgL-1 (R2=0.9999). The total phenolic content was determined by using gallic acid equivalent in $\mathrm{mgGA} / \mathrm{L}$.

\subsection{Total Antioxidant Capacity Assay}

Total antioxidant capacity assay was performed using DPPH (Sigma-Aldrich) methods by Kelebek et al. (Kelebek et al., 2017). Absorbance was measured by Agilent Carry $60 \mathrm{UV}$ - Vis at $515 \mathrm{~nm}$. The calibration curve was plotted by trolox standard solutions (Sigma-Aldrich) between 10-500 mg/L (R2=0.9985) and the total antioxidant capacity was determined in $\mu \mathrm{mol} \mathrm{TE} / \mathrm{L}$.

\section{Results}

It was found that moringa seed contains approximately $4.92 \%$ moisture, $42.15 \%$ fat, $35.54 \%$ protein, $2.98 \%$ ash, $8.44 \%$ dietary fiber and $14.41 \%$ carbohydrate in the dry matter. These values indicate that the moringa seed has very high fat and protein contents. These values are compatible with the studies done before (Abdulkarim et al., 2005; Anwar and Rashid, 2007; Manzoor et al., 2007).

Some physicochemical properties of moringa seed (Moringa oleifera) oil obtained by cold press are given in Table 1.

Table 1. Physicochemical properties of moringa oil

\begin{tabular}{|l|l|}
\hline Analysis Parameters & \multicolumn{1}{|c|}{ Results } \\
\hline Moisture content (\%) & 0.04 \\
\hline Refractive index (at $\left.40^{\circ} \mathrm{C}\right)$ & 1.4604 \\
\hline FFA (\% oleic acid equivalent) & 1.206 \\
\hline Peroxide value (meq/kg) & 9.00 \\
\hline Saponification value (mg KOH/g oil) & 185.80 \\
\hline Iodine Value (g I/100 g) & 68.42 \\
\hline Total phenolics (mg gallic acid/g) & 455.33 \\
\hline Antioxidant capacity (mM Trolox/ml) & 22.28 \\
\hline Colour 5.25\% & $4.3 \mathrm{R}-70 \mathrm{Y}$ \\
\hline
\end{tabular}


Examining Table 1, it was seen that the free fatty acid (FFA) value is $1.206 \%$. Similarly, SánchezMachado et al. determined the FFA value in crude moringa oil as 1.29\% (Sánchez-Machado et al., 2015). However, Fotouo-M et al. investigated the FFA values of moringa seeds obtained from different origins (India, Kenya and Bangladesh) and they found that the FFA values were higher in those obtained from India $(1.94 \%)$ than in others $(1.01 \%$ and $0.73 \%$, respectively) (Fotouo-M. et al., 2016). It is thought that this difference is caused by especially regional differences as well as climate and raising conditions during growth. Ruttarattanamongkol et al. determined the FFA values changed between 1.89 and 3.24\% in moringa oil obtained at different temperature and pressure conditions by using the pilot scale supercritical carbon dioxide extraction method (Ruttarattanamongkol et al., 2014). Moringa oil is similar to oleic acid-rich hazelnut oil in terms of fatty acid composition. When evaluated in this respect, it was determined that FFA value of Moringa oil is lower than $1.370 \%$ determined by Kesen et al. in crude hazelnut oil (Kesen et al., 2016). The saponification number is used to describe the average molecular weight of the fatty acids in the lipid molecule.

In this study, the saponification number of Moringa oil was determined to be $185.8 \mathrm{mg} \mathrm{KOH} / \mathrm{g}$. It was observed that saponification number changed between $160.62-198.60 \mathrm{mg} \mathrm{KOH} / \mathrm{g}$ in the previous studies (Bhutada et al., 2016; Fernandes et al., 2015; Salaheldeen et al., 2015; Sánchez-Machado et al., 2015).

Similarly, the saponification value of olive oil was found to be between $189.5-191.5 \mathrm{mg} \mathrm{KOH} / \mathrm{g}$ oil (Firestone, 2005). Ruttarattanamongkol et al. determined that the saponification values of moringa oil obtained by supercritical carbon dioxide extraction method under different temperature and pressure changed between 125.57 and 127.95. This value is lower than that of previous studies (Ruttarattanamongkol et al., 2014). It is thought that this difference is caused by the extraction of moringa oil by liquid carbon dioxide method.

It was determined that the iodine number of moringa oil obtained by cold press was $68.42 \mathrm{~g} \mathrm{I} / 100 \mathrm{~g}$. In the previous studies, it was observed that the iodine value changed between 63.94-77.17 (g I/100 g) and the value obtained was compatible with these studies (Bhutada et al., 2016; Fotouo-M. et al., 2016; Ruttarattanamongkol et al., 2014; Salaheldeen et al., 2015; Sánchez-Machado et al., 2015).

It was determined that the color value of raw moringa oil obtained by cold press was 4.3R-70Y.

Total antioxidant and total phenolic substance amounts were $22.28 \mathrm{mM}$ Trolox $/ \mathrm{mL}$ and $455.33 \mathrm{mg}$ gallic $\mathrm{acid} / \mathrm{g}$, respectively. Fernandes et al. found the antioxidant capacities of $70 \%$ and $98 \%$ ethanol extracts of Moringa oleifera as 76.7 and $50.1 \mu \mathrm{g} / \mathrm{ml}$, respectively (Fernandes et al., 2015). Ogbunugafor et al. investigated some physico-chemical and antioxidant properties of Moringa oleifera seed oil and they found the antioxidant capacity as 37.94 $\pm 0.02 \mathrm{mg}$ Ascorbic acid Equivalent/g (Ogbunugafor et al., 2011). Different concentrations of Moringa oleifera seed oil were used and antioxidant capacity was given as avarage $\%$ inhibition. $10-500 \mu \mathrm{g} / \mathrm{ml}$ samples were used and avarage $\%$ inhibitions were found to be 65 $84 \%$.

Fourteen fatty acids were identified and quantified in moringa oil. The percentages of each fatty acid are given in Table 2.

When the fatty acid composition of moringa oil obtained by cold press was examined, it was determined that oleic acid was the main fatty acid $(74.29 \%)$. It was determined that oleic acid was followed by behenic acid (6.09\%), palmitic acid (5.83\%), stearic acid (4.67\%), arachidic acid $(3.32 \%)$ and gadoleic acid $(2.37 \%)$, respectively. It was determined that the moringa oil had a total saturated fatty acid (SFA) content of about $21.39 \%$ and a total unsaturated fatty acid (TUFA) content of about $78.58 \%$.

These results are similar to the findings of the researchers investigating fatty acid compositions of some oils performed by cold press and solvent extraction methods from moringa seeds (Anwar and Rashid, 2007; Ghazali and Mohammed, 2011; Lalas and Tsaknis, 2002; Manzoor et al., 2007; Nguyen et al., 2011; Zhao and Zhang, 2012). As can be seen from Table 2; it was determined that monounsaturated fatty acid content was much higher $(\sim 77.90 \%)$ than polyunsaturated fatty acid (PUFA) content.

However, the oil of Moringa oleifera seed is included in high-oleic oils category in terms of the present fatty acid composition and has a high ratio of MUFA/SFA. The ratio of MUFA/SFA is characteristic of many oils, particularly olive oil, and can effectively reduce the risk of all-cause mortality, cardiovascular mortality, cardiovascular events and stroke (Leone et al. 2016; Schwingshackl and Hoffmann 2014). So that, M. oleifera seed oil can be used as a feasible substitute for olive oil. M. oleifera seed oil and olive oil has a similar MUFA content but in terms of nutrition, M. oleifera has a lower polyunsaturated fatty acid content which is a limiting factor and needs to be counterbalanced by the intake of other sources which are rich in PUFA (Boskou 2011; Gnagnarella et al. 2016; Leone et al. 2016). However, in the view of a technological point, the low PUFA content ensures better stability and resistance to oxygen. 
Table 2. Fatty acid composition of moringa oil

\begin{tabular}{|l|l|}
\hline Fatty acid composition (\%) & \multicolumn{1}{|c|}{ Results (\%) } \\
\hline Miristic acid (C14:0) & 0.04 \\
\hline Palmitic acid (C16:0) & 1.4604 \\
\hline Palmitoleic acid (C16:1) & 1.206 \\
\hline Heptadecenoic acid (C17:1) & 9.00 \\
\hline cis-Heptadecenoic acid (C17:1) & 185.80 \\
\hline Stearic acid (C18:0) & 68.42 \\
\hline Oleic acid (C18:1) & 455.33 \\
\hline Linoleic acid (C18:2) & 22.28 \\
\hline Linolenic acid (C18:3) & 0.0852 \\
\hline Arachidic acid (C20:0) & 3.322 \\
\hline Gadoleic acid (C20:1) & 2.3694 \\
\hline Behenic acid (C22:0) & 6.0928 \\
\hline Tricosanic acid (C23:0) & 0.0684 \\
\hline Lignoseric acid (C24:0) & 1.2867 \\
\hline SFA & 21.3851 \\
\hline MUFA & 77.9019 \\
\hline PUFA & 0.6744 \\
\hline TUFA & 78.5763 \\
\hline
\end{tabular}

It is very suitable as a natural behenic acid source due to the substantial percentage $(6.09 \%)$ of behenic acid which is present in the extracted oil. Behenic acid is used as a solidifying and structuring agent in margarine, chocolate, shortening and some foods which contain solid and semi-solid fats to make better melting down behaviors and the mouth feel, also used for removing the need to hydrogenize the oil (Abdulkarim et al., 2005; Bhutada et al., 2016; Ruttarattanamongkol et al., 2014). It has a high nutrition value and high stability as cooking and frying oil because of the high percentage of oleic acid. Vegetable oils which contain high oleic acid such as high-oleic corn, sunflower and canola have enough oxidative stability to be used in demanding applications such as frying (Bhutada et al., 2016; Petukhov et al., 1999; Warner and Knowlton, 1997).

\section{Discussion}

Moringa seed (Moringa oleifera) is very rich in crude oil (42.15\%) and protein content $(35.54 \%)$. The raw oils obtained from this seed are also very rich in oleic acid, which is a monounsaturated fatty acid. Due to these characteristics, moringa seed (Moringa oleifera) and the oils obtained from the seeds have a high nutritional value. In this study, some physicochemical characteristics and fatty acid composition of seed oil of moringa plant grown in Tamil Nadu, India have been determined. In addition to important nutrients such as protein and fat content, some properties of oil obtained by cold press from moringa seeds used in this study and nutrition and health effects of fatty acid components are discussed.

When the fatty acid composition of moringa oil obtained by cold press was examined, it was determined that oleic acid was the main fatty acid (74.29\%). It was determined that the moringa oil had a total saturated fatty acid (SFA) content of about $21.39 \%$ and a total unsaturated fatty acid (TUFA) content of about $78.58 \%$.

Since moringa leaves and seeds have both rich nutritional contents and moringa oil is rich in monounsaturated fatty acids, they can be used as a useful nutritional source for health as a food ingredient in diets. A lot of attention has been dedicated to oleic acid-rich plant oils, since an association has been established between diets rich in trans-unsaturated and saturated fatty acids and increased risk of 
cardiovascular diseases caused by high blood cholesterol levels (Siguel and Lerman, 1993).

\section{References}

Abd-Elhakim, Y.M., El Bohi, K.M., Hassan, S.K., El Sayed, S., Abd-Elmotal, S.M., 2018. Palliative effects of Moringa olifera ethanolic extract on hemato-immunologic impacts of melamine in rats. Food Chem. Toxicol. https://doi.org/10.1016/j.fct.2018.02.020

Abdulkarim, S.M., Long, K., Lai, O.M., Muhammad, S.K.S., Ghazali, H.M., 2005. Some physicochemical properties of Moringa oleifera seed oil extracted using solvent and aqueous enzymatic methods. Food Chem. 93, 253-263.

Abhishek, Rimpy, Ahuja, M., 2017. Moringa gum-g-poly(N-vinyl-2-pyrrolidone) - a potential.

Anwar, F., Rashid, U., 2007. Physiochemical characteristics of Moringa Oleifera seeds and seed oil from a wild provenance of Pakistan. Pakistan J. Bot. 39, 1443-1453.

AOAC, 1990. Official Methods of Association of Official Analytical Chemists. Association of Official Analytical chemists (AOAC). Virginia.

Azeez, F.A., Nosiru, M.O., Clement, N.A., Awodele, D.A., Ojo, D., Arabomen, O., 2013. importance of moringa oleifera tree. Elixir Agric. 55, 12959-12963.

Bhutada, P.R., Jadhav, A.J., Pinjari, D. V, Nemade, P.R., Jain, R.D., 2016. Solvent assisted extraction of oil from Moringa oleifera Lam. seeds. Ind. Crops Prod. 82, 74-80. https://doi.org/10.1016/j.indcrop.2015.12.004

Bolarinwa, I.F., Aruna, T.E., Raji, A.O., 2017. Nutritive value and acceptability of bread fortified with moringa seed powder. J. Saudi Soc. Agric. Sci. https://doi.org/10.1016/j.jssas.2017.05.002

Boskou, D., 2011. Olive oil, in: Gunstone, F.D. (Ed.), Vegetable Oils in Food Technology: Composition, Properties and Uses. Wiley-Blackwell, USA, pp. 243-271.

Cemeroğlu, B., 2018. Toplam Fenolik Bileşiklerin Tayini, in: Cemeroğlu, B. (Ed.), Gıda Analizleri. Ankara, pp. 102-108.

Chin, C.Y., Jalil, J., Ng, P.Y., Ng, S.F., 2018. Development and formulation of Moringa oleifera standardised leaf extract film dressing for wound healing application. J. Ethnopharmacol. https://doi.org/10.1016/j.jep.2017.10.016

Choi, E.J., Debnath, T., Tang, Y., Ryu, Y.B., Moon, S.H., Kim, E.K., 2016. Topical application of Moringa oleifera leaf extract ameliorates experimentally induced atopic dermatitis by the regulation of Th1/Th2/Th17 balance. Biomed. Pharmacother. https://doi.org/10.1016/j.biopha.2016.09.085

Coz-Bolaños, X., Campos-Vega, R., Reynoso-Camacho, R., Ramos-Gómez, M., Loarca-Piña, G.F., Guzmán-Maldonado, S.H., 2018. Moringa infusion (Moringa oleifera) rich in phenolic compounds and high antioxidant capacity attenuate nitric oxide pro-inflammatory mediator in vitro. Ind. Crops Prod. https://doi.org/10.1016/j.indcrop.2018.03.028

Da Porto, C., Decorti, D., Natolino, A., 2016. Microwave pretreatment of Moringa oleifera seed: Effect on oil obtained by pilot-scale supercritical carbon dioxide extraction and Soxhlet apparatus. J. Supercrit. Fluids. https://doi.org/10.1016/j.supflu.2015.08.006

Fakayode, O.A., Ajav, E.A., 2016. Process optimization of mechanical oil expression from Moringa (Moringa oleifera) seeds. Ind. Crops Prod. https://doi.org/10.1016/j.indcrop.2016.06.017 
Fernandes, D.M., Sousa, R.M.F., Oliveira, A., Morais, S.A.L., Richter, E.M., Muñoz, R.A.A., 2015. Moringa oleifera: A potential source for production of biodiesel and antioxidant additives. Fuel $146,75-80$.

Firestone, D., 2005. Olive Oil, in: Shahidi, F. (Ed.), Bailey’s Industrial Oil \& Fat Products. WileyInterscience publication, New Jersey, pp. 303-332.

Fotouo-M., H., du Toit, E.S., Robbertse, P.J., 2016. Effect of storage conditions on Moringa oleifera Lam. seed oil: Biodiesel feedstock quality. Ind. Crops Prod. https://doi.org/10.1016/j.indcrop.2016.01.032

Ghazali, H.M., Mohammed, A.S., 2011. Moringa (Moringa oleifera) Seed Oil: Composition, Nutritional Aspects, and Health Attributes, in: Watson, R.R., Patel, V.B. (Eds.), Nuts and Seeds in Health and Disease Prevention. pp. 787-793.

Gnagnarella, P., Salvini, S., Parpinel, M., 2016. Food Composition Database for Epidemiological Studies in Italy.

González-Trujano, M.E., Martínez-González, C.L., Flores-Carrillo, M., Luna-Nophal, S.I., Contreras-Murillo, G., Magdaleno-Madrigal, V.M., 2018. Behavioral and electroencephalographic evaluation of the anticonvulsive activity of Moringa oleifera leaf nonpolar extracts and one metabolite in PTZ-induced seizures. Phytomedicine. https://doi.org/10.1016/j.phymed.2017.12.009

Kelebek, H., Selli, S., Kola, O., 2017. Quantitative determination of phenolic compounds using LCDAD-ESI-MS/MS in cv. Ayvalik olive oils as affected by harvest time. J. Food Meas. Charact. $11,226-235$.

Kesen, S., Sonmezdag, A.S., Kelebek, H., Selli, S., 2016. Ham ve Rafine Fındık Yağlarının Yă̆ Asitleri Bileşimi. Çukurova Tarım ve Gıda Bilim. Derg. 31, 79-84.

Lalas, S., Tsaknis, J., 2002. Characterization of Moringa oleifera Seed Oil Variety "Periyakulam 1." J. Food Compos. Anal. 15, 65-77.

Latif, H.H., Mohamed, H.I., 2016. Exogenous applications of moringa leaf extract effect on retrotransposon, ultrastructural and biochemical contents of common bean plants under environmental stresses. South African J. Bot. https://doi.org/10.1016/j.sajb.2016.07.010

Leone, A., Spada, A., Battezzati, A., Schiraldi, A., Aristil, J., Bertoli, S., 2016. Moringa oleifera Seeds and Oil: Characteristics and Uses for Human Health. Int. J. Mol. Sci. 17, 2141.

Lutterodt, H., Slavin, M., Whent, M., Turner, E., Yu, L., 2011. Fatty acid composition, oxidative stability, antioxidant and antiproliferative properties of selected cold-pressed grape seed oils and flours. Food Chem. 128, 391-399.

Manzoor, M., Anwar, F., Iqbal, T., Bhanger, M.I., 2007. Physico-Chemical Characterization of Moringa concanensis Seeds and Seed Oil. J Am Oil Chem Soc 84, 413-419.

Martins, P.F., De Melo, M.M.R., Silva, C.M., 2016. Techno-economic optimization of the subcritical fluid extraction of oil from Moringa oleifera seeds and subsequent production of a purified sterols fraction. J. Supercrit. Fluids. https://doi.org/10.1016/j.supflu.2015.07.031

Mat Yusoff, M., Gordon, M.H., Ezeh, O., Niranjan, K., 2016. Aqueous enzymatic extraction of Moringa oleifera oil. Food Chem. https://doi.org/10.1016/j.foodchem.2016.05.050

Matshediso, P.G., Cukrowska, E., Chimuka, L., 2015. Development of pressurised hot water extraction (PHWE) for essential compounds from Moringa oleifera leaf extracts. Food Chem. https://doi.org/10.1016/j.foodchem.2014.09.047 
Nguyen, H.N., Gaspillo, P. -a. D., Maridable, J.B., Malaluan, R.M., Hinode, H., Salim, C., Huynh, H.K.P., 2011. Extraction of oil from Moringa oleifera kernels using supercritical carbon dioxide with ethanol for pretreatment: Optimization of the extraction process. Chem. Eng. Process. Process Intensif. 50, 1207-1213.

Ogbunugafor, H.A., Eneh, F.U., Ozumba, A.N., Igwo-Ezikpe, M.N., 2011. Physico-chemical and Antioxidant Properties of Moringa oleifera Seed Oil. Pakistan J. Nutr. 10, 409-414.

Omotoso, G.O., Gbadamosi, I.T., Olajide, O.J., Dada-Habeeb, S.O., Arogundade, T.T., Yawson, E.O., 2018. Moringa oleifera phytochemicals protect the brain against experimental nicotine-induced neurobehavioral disturbances and cerebellar degeneration. Pathophysiology. https://doi.org/10.1016/j.pathophys.2017.12.003

Petukhov, I., Malcolmson, L.J., Przybylski, R., Armstrong, L., 1999. Frying performance of genetically modified canola oils. J. Am. Oil Chem. Soc. 76, 627-632.

Porzucek, H., Raznikiewicz, L., 1990. Fatty acid composition and lipoxygenase activity of flours and protein isolates from leguminous plants. Swedish J Agric Res 20, 31-34.

Rashid, U., Anwar, F., Moser, B.R., Knothe, G., 2008. Moringa oleifera oil: A possible source of biodiesel. Bioresour. Technol. https://doi.org/10.1016/j.biortech.2008.03.066

Ruttarattanamongkol, K., Siebenhandl-Ehn, S., Schreiner, M., Petrasch, A.M., 2014. Pilot-scale supercritical carbon dioxide extraction, physico-chemical properties and profile characterization of Moringa oleifera seed oil in comparison with conventional extraction methods. Ind. Crops Prod. https://doi.org/10.1016/j.indcrop.2014.03.020

Salaheldeen, M., Aroua, M.K., Mariod, A.A., Cheng, S.F., Abdelrahman, M.A., Atabani, A.E., 2015. Physicochemical characterization and thermal behavior of biodiesel and biodiesel-diesel blends derived from crude Moringa peregrina seed oil. Energ Convers Manag. 92, 535-542.

Sánchez-Machado, D.I., López-Cervantes, J., Núñez-Gastélum, J.A., de la Mora-López, G.S., LópezHernández, J., Paseiro-Losada, P., 2015. Effect of the refining process on Moringa oleifera seed oil quality. Food Chem. 187, 53-57.

Schwingshackl, L., Hoffmann, G., 2014. Monounsaturated fatty acids, olive oil and health status: a systematic review and meta-analysis of cohort studies. Lipids Heal. Dis 13, 154.

Siguel, E.N., Lerman, R.H., 1993. Trans-fatty acid patterns in patients with angiographically documented coronary artery disease. Am J Cardiol 71, 916-920.

Vaknin, Y., Mishal, A., 2017. The potential of the tropical "miracle tree" Moringa oleifera and its desert relative Moringa peregrina as edible seed-oil and protein crops under Mediterranean conditions. Sci. Hortic. (Amsterdam). https://doi.org/10.1016/j.scienta.2017.07.039

Valdés-Rodríguez, O.A., Giadrossich, F., Pérez-Vázquez, A., Moreno-Seceña, J.C., 2018. Above- and below-ground biomass and allometry of Moringa oleifera and Ricinus communis grown in a compacted clayey soil. Flora Morphol. Distrib. Funct. Ecol. Plants. https://doi.org/10.1016/j.flora.2018.02.002

Villaseñor-Basulto, D.L., Astudillo-Sánchez, P.D., del Real-Olvera, J., Bandala, E.R., 2018. Wastewater treatment using Moringa oleifera Lam seeds: A review. J. Water Process Eng. https://doi.org/10.1016/j.jwpe.2018.03.017

Warner, K., Knowlton, S., 1997. Frying quality and oxidative stability of high-oleic corn oils. J Am Oil Chem Soc 74, 1317-1322. 
Yu, L., Haley, S., Perret, J., Harris, M., 2002. Antioxidant properties of hard winter wheat extracts. Food Chem. 78, 457-461.

Zhao, S., Zhang, D., 2013. Supercritical fluid extraction and characterisation of Moringa oleifera leaves oil. Sep. Purif. Technol. https://doi.org/10.1016/j.seppur.2013.07.046

Zhao, S., Zhang, D., 2012. A parametric study of supercritical carbon dioxide extraction of oil from Moringa oleifera seeds using a response surface methodology. Sep Purif Technol 113, 9-17. 